\title{
A DESCRIPTIVE STUDY TO ASSESS THE LEVEL OF JOB STRESS AMONG STAFF NURSES WORKING IN CRITICAL CARE UNIT IN SELECTED HOSPITALS AT ERODE.
}

Mrs. D. Thulasimani* | Dr. Ramesh Kumari**

*Ph.D. Scholar, Himalayan University, Itanagar, Arunachal Pradesh, India. ${ }^{* *}$ Research Supervisor, Himalayan University, Itanagar, Arunachal Pradesh, India. DOI: http://doi.org/10.47211/idcij.2020.v07i03.007

Received $5^{\text {th }}$ June 2020, Accepted $20^{\text {th }}$ June 2020, Available online $10^{\text {th }}$ July 2020.

\section{ABSTRACT}

A descriptive study to assess the level of job stress among staff nurses working in critical care unit in selected hospital of Erode. The objective of study was to assess the level of job stress among staff nurses working in selected hospital of critical care unit and, to find out the association between level of job stress with selected demographic variables of staff nurses working in critical care unit. In this study a non-experimental research design was used to assess the level of job stress among the staff nurses working in critical care unit. The sampling method used for this study was non-probability purposive sampling technique from the critical care unit staff. The finding of the study showed that out of 50 samples taken for the study $10 \%$ staffs were calm and $8 \%$ staffs have low stress, $20 \%$ staffs have moderate stress and $6 \%$ were have severe stress and the staff nurses in highly dangerous stress were $6 \%$.

Key Words: Job Stress, Staff Nurse, Critical care Unit.

\section{ABOUT AUTHORS:}

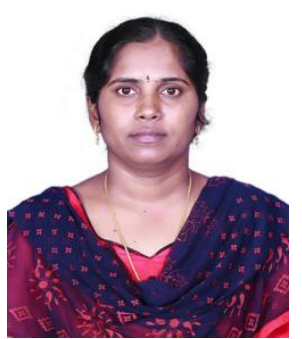

Author Mrs. D. Thulasimani is Professor in Sakthii College of Nursing, Oddanchatram, Tamilnadu, India. She is active researcher and has attended various Seminars and conferences.

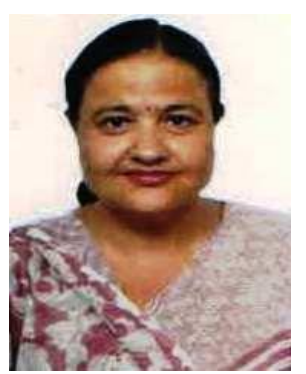

Author Dr. Ramesh Kumari is Principal at Mai Bhago College of Nursing, Tarn Taran, Punjab, India. She is Research Supervisor in Himalayan University, Itanagar. She has attended and organised Workshops, Seminars and Conferences. She has published various research articles in National and International Journals. 


\section{INTRODUCTION}

Stress occurs when the body prepares itself over and over again, for an activity such as combat or escape that really never takes place. Stress is not inherently deleterious however each individuals cognitive appraisal their perception and interpretation gives.

Although job stress appears in all professions, jobs dealing with people are associated with serious stress. Nursing is one of these jobs and nurses suffer from high levels of job stress. As recommended by the many studies, job stress is related to decreased creativity and job satisfaction, lower rate of timely decision making, decreased quality of care, increased errors, decreased motivation, depression, detachment, decreased mental and physical well-being, sleep disorders, depression, burnout, absenteeism, lower job satisfaction, and physical problems.

Stress has observed among critical care unit nurses, due to their close contact with patients in distress and at the risk of death. This situation becomes worse due to the need for direct and intensive care. The Causes for job stress was identified that there is heavy workload, urgency of work to be performed, death and dying patients, role conflict, lack of autonomy in practice, insufficient knowledge base, lack of support, fear of making mistakes, limitations on organization level, unsafe work place

\section{NEED FOR THE STUDY}

Stress is a usual and normal part of our daily lives. It is a normal physical reaction to an internal or external pressure that is placed on a person's system. Extended periods of stress can cause destructive changes in the body such as depression, heart disease, cancer, stroke, ulcers, back pain, headaches, raised blood pressure, indigestion, and various other problems

Occupational stress results in considerable costs to organizations in terms of absenteeism, attrition rate, injury claims, infection rates, errors in treating patient, reduced productivity, and health care resources. Reduced productivity in turn can lead to increased staff conflicts, recruitment and retention problems, burnout, absenteeism, litigation and rapid turn-over, and inadequate job satisfaction (Nakasis and Ouzouni, 2008, Hanson et al., 2017)

\section{STATEMENT OF THE PROBLEM}

A descriptive study to assess the level of job stress among staff nurses working in critical care units in selected hospital at erode.

\section{OBJECTIVES}

To assess the level of job stress among staff nurses working in critical care units of selected hospital at erode

$>$ To find out the association between level of job stress with selected demographic variables of staff nurses working in critical care units of selected hospital erode

\section{HYPOTHESIS}

D H1: There is significant association between the level of job stress with selected demographic variables of staff nurses working in critical care units of selected hospital.

\section{METHODOLOGY:}

A Descriptive research approach -non-experimental research design was used to assess the level of stress among the staff nurses working in of critical care units of selected Hospitals at erode. The sample was selected by non-probability purposive sampling technique .Population consists of staff nurses who are working in critical care units of selected Hospitals and who fulfilled the inclusion criteria. The tool used for the study was part -A Demographic variables and Part -B Expanded nurses stress scale. Data collection was done by the investigator after administering the stress scale to the study subjects. The collected data was analyzed by using descriptive \& inferential statistics

RESULT:

The study findings revealed that $75 \%$ of staff nurses were in age group of $20-25 \& 25 \%$ were in age group of $26-35$. On gender basis $10 \%$ were male \& $90 \%$ were female. Based on marital status $65 \%$ were single $\& 35 \%$ were married and that $85 \%$ are without child and $15 \%$ are with child. In case of educational qualification GNM staffs were $70 \% \& 30 \%$ were B.Sc. Based on area of work $65 \%$ were CCU staffs CCU staffs \&35\% were ICCU staffs. on basis of work experience $30 \%$ of staffs were having $>12$ month experience, $20 \%$ having $13-24$ month experience \& $50 \%$ for staffs with $25-30$ month $\&<36$ month experience.

The finding of the study showed that out of 50 samples $10 \%$ staffs were calm and $8 \%$ staffs were having low stress, $20 \%$ staffs having moderate stress and $6 \%$ were having severe stress and the staff nurses in highly dangerous stress were $6 \%$. Association study reveals that age $(39.11 \%)$ is significant: gender $(1.95 \%)$ is not significant, marital status (5.99\%) is significant, no of children (6.09\%)is not significant, educational qualification $(73.98 \%)$ is significant, area of work $(3.08 \%$ is not significant, work experience $(7.2 \%)$ is not significant, satisfaction with salary $(5.52 \%)$ is significant. 


\section{CONCLUSION}

The present study concluded that highest mean scores were observed in moderate stress level. This job stress is due to Lack of professional recognition and work condition are the most common categories of stressor among nurses therefore there was statistical significant association to moderate job stress level Hence it concluded that there is a need for stress management intervention.

\section{REFERENCES}

1. Andrew McVicar, (2003): Workplace stress in nursing: a literature review Journal of Advanced Nursing, 44(6): 633-642.

2. Bhatia, \& Nirmanmoh, B. (2010). Occupational Stress amongst Nurses from Two Tertiary Care Hospital in Delhi. Australasian Medical Journal, 1: 1-2.

3. Brunero S., Cowan D., Grochulski A., et al.: Stress management for nurses. Sydney; New South Wales Nurses' Association 2006; 4-33.

4. Dr. Amy Sickel, Committee Chairperson, 2016 Psychological Stress in Critical Care Nurses; 130 July 2017 International Journal of Advanced Science and Research assess the level of stress among staff nurses working in critical care unit in selected Hospital 11-12.

5. Evans L.: An exploration of district nurses' perception of occupational stress. Br J Nurs. 2002; 11(8): $576-585$.

6. Franco AC.1994 striving to care: A qualitative study of stress in nursing. Department of Educational Psychology and Counseling. Montreal, Canada: Thesis, Faculty of Education, McGill University;

7. French SE., Lenton R., Walters V., et al 2001. An empirical evaluation of on expanded Nursing Stress Scale. J NursMeas: 161-178.

8. Kawano Y.2008: Association of Job related Stress Factors with Psychological and Somatic Symptoms among Japanese Hospital Nurses: Effect of Departmental Environment in Acute Care Hospitals. J Occup Health.:79-85.

9. Lewis DJ, Robinson JA 1992 ICU nurses coping measures: Response to work-related Stressors. Crit Care Nurs12:18-25.

10. Marshall J. London, Chicester 2010 Stress among nurses. Editors. White Collar and Professional Stress.

11. Saini R., Kaur S. \& Dasm K.2011: Assessment of stress and burnout among intensive care nurses at a tertiary care hospital. Journal of Mental Health and Human Behaviour. ; 43-48.

12. Welker-Hood K. Does workplace stress lead to accident or error? Many nurses feel the pressure. American Journal of Nursing. 2006; 106 (9): 104.

13. Xianyu Evans L.: An exploration of district nurses' perception of occupational stress. Br J Nurse. 2002; 11(8): $576-585$. 